\title{
ANALISIS BAURAN PEMASARAN FRANCHISE O'CHICKEN DI KECAMATAN BUKITRAYA KOTA PEKANBARU
}

\author{
AZIZAH AZMI, YUSMINI , DAN EVY MAHARANI \\ Jurusan Agribisnis Fakultas Pertanian Universitas Riau \\ Kampus Binawidya Simpang Baru Kecamatan Tampan Pekanbaru \\ Email: azizahazmi77@gmail.com
}

\begin{abstract}
ABSTRAK
Usaha franchise $O$ 'Chicken di Kecamatan Bukitraya mulai dibuka dan diresmikan pada tanggal 15 Mei 2015 oleh Bapak Markarius Anwar, dengan konsep penjualan produk olahan ayam organik. Penelitian ini bertujuan untuk menganalisis bauran pemasaran konsumen O'Chicken. Metode penelitian yang digunakan adalah metode survey dengan responden penelitian berjumlah 50 responden yang telah berusia $\geq 15$ tahun, berbelanja di O'Chicken lebih dari 1 kali. Data dianalisis menggunakan skala Likert. Berdasarkan hasil penelitian dapat disimpulkan bahwa analisis bauran pemasaran pembelian O'Chicken dipengaruhi oleh lima variabel bauran pemasaran seperti produk, harga, lokasi, promosi dan layanan mendapatkan skor rata-rata 4,00 dengan kategori berpengaruh. . Variabel produk dengan skor rata-rata 4,23 merupakan kategori sangat berpengaruh, indikator produk yang mendapat skor tertinggi adalah kebersihan produk dengan skor 4,60 kategori sangat berpengaruh. Variabel harga dengan skor rata-rata 4,09 dikategorikan sebagai berpengaruh, indikator harga yang mendapat skor tertinggi adalah harga sesuai kualitas produk dengan skor 4,24 kategori sangat berpengaruh. Variabel tempat dengan skor rata-rata 3,81 dikategorikan cukup berpengaruh, indikator tempat yang mendapat skor tertinggi adalah lokasi yang strategis dan menarik dengan skor 4,18 kategori berpengaruh. Variabel promosi dengan skor rata-rata 3,58 dengan kategori berpengaruh, indikator promosi yang mendapat skor tertinggi adalah promosi menggunakan spanduk atau spanduk dan promosi mulut-ke-mulut dengan skor 3,66 kategori berpengaruh. Variabel layanan dengan skor rata-rata 4,29 dengan kategori sangat berpengaruh, indikator yang mendapat skor tertinggi adalah layanan ramah dan responsif dengan skor 4,34 kategori sangat berpengaruh.
\end{abstract}

\section{Kata Kunci: Bauran pemasaran, Keputusan konsumen, Konsumen, Ayam Organik}

\section{PENDAHULUAN}

Bisnis kuliner merupakan bisnis yang sedang berkembang di Indonesia, saat ini munculnya berbagai makanan yang unik, wisata kuliner, dan trend kuliner sebagai gaya hidup masyarakat. Pekanbaru merupakan salah satu kota yang memiliki prospek untuk mengembangkan berbagai macam usaha kuliner, dengan berbagai skala usaha sampai dengan skala makro.

Salah satu jenis usaha yang mulai marak di berbagai daerah termasuk di Pekanbaru yaitu usaha franchise, franchise adalah badan usaha atau perorangan yang memberikan hak kepada pihak lain untuk memanfaatkan atau menggunakan hak atas penemuan dari ciri khas usaha yang dimilikinya. Kegiatan franchise adalah cara untuk mengembangkan atau melebarkan sayap usaha melalui kerja Pekanbaru 
sama dengan berbagai pihak yang mempunyai modal yang ingin membuka usaha tetapi tidak memiliki brand yang bagus dan terkenal.

Ayam goreng adalah makanan cepat saji yang paling digemari semua kalangan usia, dimulai dari anak-anak, remaja, hingga dewasa. Perkembangan usaha ayam goreng sangat pesat dan memiliki persaingan yang tinggi. Banyak rumah makan yang menjual ayam goreng dengan berbagai macam alternatif produk yang ditawarkan juga disertai dengan brand atau keunggulan yang dimiliki.

Meningkatnya kesadaran masyarakat akan pentingnya hidup sehat membuat usaha makanan organik, khususnya menu masakan ayam organik menjadi peluang bisnis yang menggiurkan. Meningkatnya permintaan ayam organik dari tahun ketahun, mendorong produsen untuk berinovasi dalam menawarkan produk ayam organik yang sesuai dengan keinginan konsumen baik dari segi rasa, harga, tempat, promosi dan pelayanan. Ayam goreng organik dengan brand O'Chicken merupakan salah satu inovasi produk yang berasal dari peternakan PT.Elha Narita Perkasa dan kemudian daging ayam diolah menjadi fried chicken. Outlet $O^{\prime}$ Chicken ini memiliki banyak cabang dibeberapa kecamatan di Kota Pekanbaru, salah satunya berada di Kecamatan Bukitraya yang bertempat di Jalan Utama Tengku Bey Kota Pekanbaru.

Sebagai salah satu usaha rumah makan ayam organik yang relatif baru di Pekanbaru, tentu membutuhkan pola pemasaran yang tepat. Untuk itu penelitian ini ditujukan untuk menganalisis bauran pemasaran franchise o'chicken di Kecamatan Bukitraya Kota Pekanbaru.

\section{METODOLOGI}

Penelitian ini dilaksanakan di outlet O'Chicken yang berada di Kecamatan Bukit Raya Kota Pekanbaru. Penelitian dilaksanakan pada bulan April 2017 hingga bulan Oktober 2018, dengan pertimbangan bahwa ayam goreng O'Chicken merupakan salah satu usaha yang cukup menarik perhatian konsumen, dengan kualitas ayam yang organik. Seiring dengan perkembangan jaman yang semakin maju, masyarakat semakin peduli dengan pola hidup sehat dimulai dengan mengkonsumsi makanan yang berkualitas organik maka O'Chicken membuat suatu inovasi baru yaitu ayam goreng dan jenis makanan olahan lainnya yang berkualitas organik.

Penelitian ini menggunakan metode survey. Sampel diambil dengan menggunakan metode purposive sampling dengan kriteria konsumen yang telah berumur $>15$ tahun dan pernah membeli produk $O$ 'Chicken. Populasi adalah jumlah konsumen yang berbelanja dalam satu bulan pada minggu I,II,III, dan IV yang di ambil sebagai sampel dari populasi tersebut pada bulan pengamatan. Jumlah sampel ditentukan dengan menggunakan taraf kesalahan yang diterima secara ilmiah sebesar 5 persen, sehingga diperoleh sampel penelitian sebanyak 50 orang.

140 Analisis Bauran Pemasaran Franchise O’chicken Di Kecamatan Bukitraya Kota Pekanbaru 
Data yang digunakan dalam penelitian ini adalah data primer dan data sekunder, data primer adalah data yang diperoleh secara langsung sedangkan data sekunder adalah data yang diperoleh peneliti dari sumber yang sudah ada. Data primer dalam penelitian ini berupa pernyataan konsumen terhadap analisis dari bauran pemasaran dan keputusan pembelian konsumen pada usaha $O$ 'Chicken dan data sekunder yang diperlukan seperti gambaran umum tempat penelitian.

Data dianalisis menggunakan metode statistika kualitatif yang dikuantitatifkan dalam bentuk ordinal. Data dikumpulkan dan dianalisis sesuai dengan kondisi yang ada dan ditabulasikan ke dalam bentuk tabel sesuai dengan tujuan penelitian, untuk melihat pengaruh bauran pemasaran $O^{\prime}$ Chicken menggunakan skala likert. Menurut Sugiyono (2015), Instrumen dengan skala likert akan berguna, bila peneliti ingin melakukan pengukuran secara keseluruhan tentang suatu topic, pendapat, atau pengalaman. Skala likert digunakan untuk mengembangkan instrumen yang digunakan untuk mengukur sikap, persepsi, dan pendapat seseorang atau sekelompok orang terhadap potensi dan permasalahan suatu objek, rancangan suatu produk, proses membuat produk dan produk yang telah dikembangkan atau diciptakan sebagaimana ditampilkan pada Tabel 1.

Tabel 1 Skor Penilaian Bauran Pemasaran Terhadap Keputusan Pembelian Konsumen di O'Chicken di Kecamatan Bukitraya

\begin{tabular}{lll}
\hline Kategori & Skala & Skor \\
\hline Sangat Tidak Berpengaruh & 1 & $1-1,79$ \\
Tidak Berpengaruh & 2 & $1,80-2,59$ \\
Cukup Berpengaruh & 3 & $2,60-3,39$ \\
Berpengaruh & 4 & $3,40-4,19$ \\
Sangat Berpengaruh & 5 & $4,20-5,00$ \\
\hline S
\end{tabular}

Sumber : Sugiyono (2015)

Variabel penelitian dan pengukuran terbagi dari lima variabel yaitu produk, harga, tempat, promosi dan pelayanan, sebagaimana ditampilkan pada Tabel 2.

Tabel 2. Variabel pengukuran bauran pemasaran

\begin{tabular}{|c|c|c|c|}
\hline Konsep & $\begin{array}{c}\text { Sub- } \\
\text { Variabel }\end{array}$ & Indikator & Parameter \\
\hline \multirow[t]{2}{*}{$\begin{array}{l}\text { Marketing } \\
\text { mix } \\
\text { (Bauran } \\
\text { pemasaran) } \\
(\mathrm{X})\end{array}$} & $\begin{array}{l}\text { Product } \\
\text { (Produk) }\end{array}$ & $\begin{array}{l}\text { - Rasa ayam } \\
\text { - Kualitas ayam } \\
\text { - Kerenyahan ayam } \\
\text { - Warna ayam } \\
\text { - Tekstur ayam } \\
\text { - Variasi/produk olahan } \\
\text { lainnya } \\
\text { - Kebersihan } \\
\text { - Paket produk }\end{array}$ & $\begin{array}{l}\text { - Rasa dari ayam goreng O'Chicken menjadi } \\
\text { pertimbangan pembelian konsumen. } \\
\text { - Kualitas ayam goreng organik O'Chicken. } \\
\text { - Kerenyahan dan gurihnya ayam goreng } \\
\text { - Warna ayam O'Chicken } \\
\text { - Tekstur ayam O'Chicken } \\
\text { - Variasi produk(chicken katsu, cordon bleu, tomyam, } \\
\text { ayam lada hitam, ayam bakar, burger, dan sup ayam) } \\
\text { - Kebersihan produk saat proses pengolahan } \\
\text { - Tersedianya paket produk }\end{array}$ \\
\hline & $\begin{array}{l}\text { Price } \\
\text { (Harga) }\end{array}$ & $\begin{array}{l}\text { - Keterjangkauan harga. } \\
\text { - Kesesuaian harga. }\end{array}$ & $\begin{array}{l}\text { - Keterjangkauan harga dengan produk yang disajikan } \\
\text { - Harga sesuai dengan kualitas produk yang diterima oleh } \\
\text { konsumen. }\end{array}$ \\
\hline
\end{tabular}




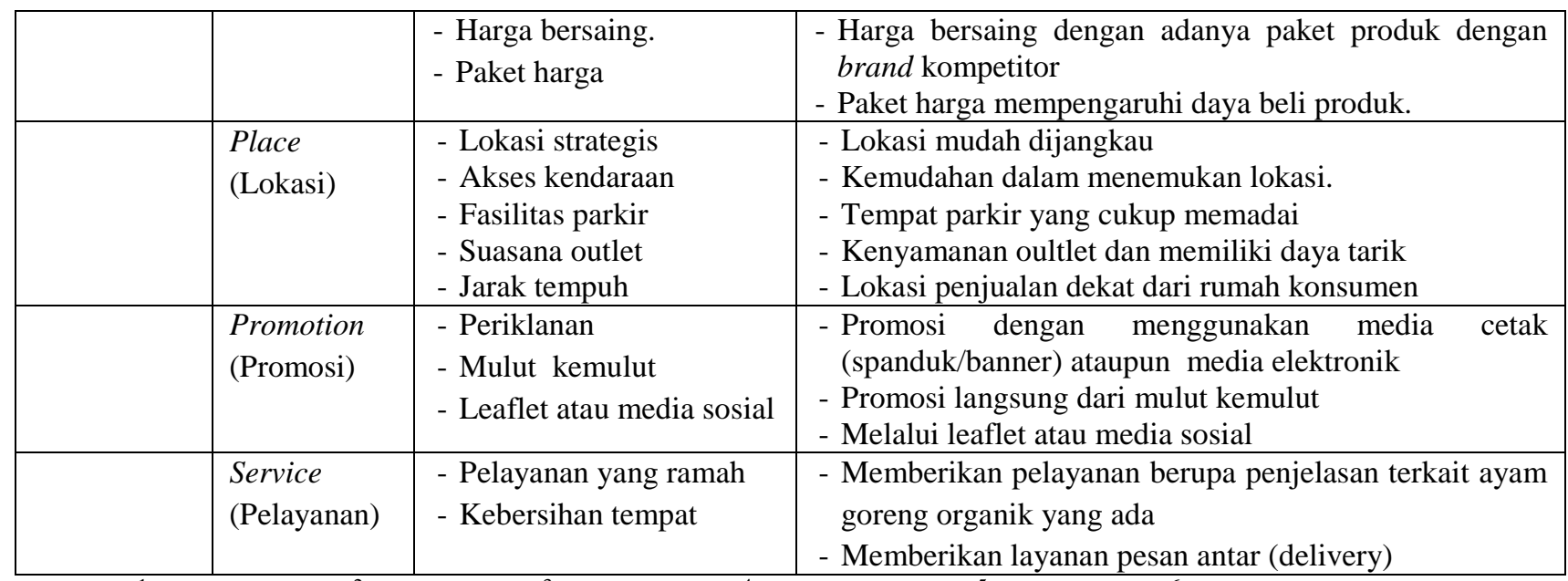

Sumber : ${ }^{1}$ Assauri (2011), ${ }^{2}$ Jones (2000), ${ }^{3}$ Kotler (2008), ${ }^{4}$ Hurriyati (2010), ${ }^{5}$ Shimp (2000), ${ }^{6}$ Zeithaml dan Bitner (2003)

\section{HASIL DAN PEMBAHASAN}

\section{Profil Usaha O'Chicken}

O'Chicken merupakan usaha makanan cepat saji (fast food) dengan menu utama makanan yang berbahan baku ayam organik. Usaha yang diamati dan dianalisis terletak di Jalan Utama Tengku Bey Kecamatan Bukitraya Kota Pekanbaru berdiri pada tanggal 11 Maret 2015. Ayam organik ini diproduksi di Kabupaten Jombang dan Kabupaten Purwakarta yang didistribusikan pada masingmasing franchise O'Chicken yang tersebar di wilayah Indonesia. Selanjutnya ayam organik ini diolah menjadi ayam goreng organik, dengan konsep pelayanan dan juga rasa atau takaran penggunaan bumbu yang sudah sesuai dengan standar yang sudah ditentukan.

Pemasaran adalah kegiatan usaha yang berkaitan dengan mengalirnya barang dan jasa dari produsen sampai ke konsumen. Pemasaran O’Chicken dilakukan dengan dua pola pemasaran yaitu konsumen datang langsung ke $O$ 'Chicken membeli produk atau menggunakan jasa delivery disekitar daerah usaha $O^{\prime}$ Chicken dengan jarak $2-5 \mathrm{~km}$, jasa antar diberlakukan jika pembeli berbelanja minimal Rp.50.000 atau lokasi delivery berada ditempat yang sama.

\section{Analisis Bauran Pemasaran}

Salah satu upaya untuk mengetahui tingkat keputusan konsumen O'Chicken Bukitraya terhadap bauran pemasaran yang ditetapkan adalah dengan mengetahui tanggapan dari responden mengenai variabel bauran pemasaran yang terdiri dari produk, harga, tempat, promosi dan pelayanan. 


\section{Produk}

Indikator produk yang digunakan adalah merek dagang, kemasan produk, kualitas produk dan pelayanan, sebagaimana ditampilkan pada Tabel 3.

Tabel 3. Tanggapan responden dan skor variabel produk pada bauran pemasaran (marketing mix) di O'Chicken Bukitraya

\begin{tabular}{clll}
\hline Variabel & Indikator & Skor & \multicolumn{1}{c}{ Kategori } \\
\hline Produk & Rasa & 4,18 & Berpengaruh \\
& Kualitas & 4,32 & Sangat Berpengaruh \\
& Kerenyahan & 4,20 & Sangat Berpengaruh \\
Warna & 4,20 & Sangat Berpengaruh \\
Tekstur & 4,34 & Sangat Berpengaruh \\
Variasi Produk & 4,04 & Berpengaruh \\
& Kebersihan Produk & 4,60 & Sangat Berpengaruh \\
& Tersedianya Paket Produk & 3,96 & Berpengaruh \\
\hline Rata-rata indikator & $\mathbf{4 , 2 3}$ & Sangat Berpengaruh \\
\hline
\end{tabular}

Tabel 3 skor tertinggi ada pada indikator kebersihan produk dengan skor 4,60 dengan kategori sangat berpengaruh, hal ini mengindikasikan bahwa merupakan tolak ukur utama bagi konsumen. Seluruh tahapan produksi $O^{\prime}$ Chicken dilakukan dengan proses yang terjamin kebersihannya. Proses produksi yang dilakukan dengan cara higienis menjadi pertimbangan bagi konsumen dalam proses pembelian, walaupun harga yang ditetapkan lebih tinggi dibandingkan dengan produk lainnya.

Pada indikator rasa mendapat skor 4,18 dengan kategori berpengaruh. Rasa dapat menentukan penerimaan konsumen terhadap suatu produk, termasuk ayam goreng. Ayam $O$ 'Chicken memiliki rasa dengan ciri khas tersendiri dari lidah konsumen, karena tidak menggunakan bahan penyedap.

Indikator kualitas dari ayam $O^{\prime}$ Chicken mendapat skor 4,32 dengan kategori sangat berpengaruh. Ayam $O$ 'Chicken diolah dari daging ayam organik yang dilumuri tepung bumbu racikan Non-MSG atau Vetsin menjadikan fried chicken lebih lezat dan lebih sehat, sehingga O'Chicken dipercaya konsumen untuk dijadikan menu makanan utama dan juga menjadi pilihan bekal anak ataupun untuk dikonsumsi pribadi

Pada variabel produk terdapat indikator kerenyahan dari ayam $O^{\prime}$ Chicken yang mendapat skor 4,20 dengan kategori sangat berpengaruh. Menurut pendapat konsumen hasil olahan tepung yang digunakan untuk menggoreng ayam menghasilkan tingkat kematangan yang dapat mempengaruhi kerenyahan dari ayam goreng. Hal ini menjadi faktor penarik bagi konsumen untuk mengkonsumsi ayam $O$ 'Chicken.

Pada indikator warna mendapat skor 4,20 dengan kategori sangat berpengaruh, hal ini dapat diartikan bahwa konsumen menyukai warna dari ayam $O^{\prime}$ Chicken terlihat menarik dengan tampak luar berwarna kuning keemasan dan daging ayamnya berwarna putih, sehingga menarik selera dan menjadi daya tarik konsumen untuk membeli. 
Indikator tekstur mendapat skor 4,34 dengan kategori sangat berpengaruh, ini menunjukkan tekstur memiliki peranan penting bagi suatu produk makanan terutama ayam goreng. Menurut pendapat konsumen tekstur dari ayam goreng $O^{\prime}$ Chicken lebih lembut karena daging ayam yang dimasak dengan tingkat kematangan yang sempurna, sedangkan daging ayam yang belum matang terksturnya kenyal dan sulit dikunyah.

Pada indikator jenis produk lainnya mendapat skor 4,04 dengan kategori berpengaruh, karena konsumen dapat mengkonsumsi atau mencoba menu lain seperti chicken cordon bleu, ayam lada hitam, tomyam, chicken katsu, burger dan sup ayam. Adanya variasi menu yang ditawarkan oleh O'Chicken bertujuan untuk menghindari kejenuhan konsumen terhadap ayam goreng fried chicken.

Indikator dengan nilai skor terkecil yaitu tersedianya paket produk, diberi nilai oleh konsumen dengan skor 3,96 dengan kategori berpengaruh, ini menunjukkan bahwa paket produk O'Chicken belum menjadi pertimbangan bagi konsumen. Tetapi dengan adanya paket produk, konsumen dapat membeli ayam dengan harga lebih terjangkau dan lebih hemat jika dibandingkan membeli ayam dalam jumlah satuan.

\section{Harga}

Indikator yang digunakan pada variabel harga adalah keterjangkauan harga, kesesuaian harga dengan kualitas produk, menyediakan paket harga bersaing dengan brand kompetitor dan harga paket yang lebih terjangkau. Tanggapan responden terhadap skor variabel pada bauran pemasaran O'Chicken dapat dilihat pada Tabel 4.

Tabel 4. Tanggapan responden dan skor variabel harga pada bauran pemasaran (marketing mix) di O'Chicken Bukitraya

\begin{tabular}{clrr}
\hline Variabel & Indikator & Skor & Kategori \\
\hline Harga & Keterjangkauan Harga & 4,02 & Berpengaruh \\
& Harga sesuai dengan kualitas produk & 4,24 & Sangat Berpengaruh \\
& Paket harga bersaing dengan brand kompetitor & 4,08 & Berpengaruh \\
& Harga paket lebih terjangkau & 4,20 & Berpengaruh \\
\hline & Rata-rata indikator & 4,09 & Berpengaruh \\
\hline
\end{tabular}

Tabel 4 menunjukkan bahwa indikator harga sesuai dengan kualitas produk memperoleh skor tertinggi yaitu 4,24 dengan kategori sangat berpengaruh. Menunjukkan bahwa konsumen dapat menikmati ayam $O$ 'Chicken dengan kualitas ayam organik dengan harga yang terjangkau. Konsumen mendapatkan kesesuaian harga dengan kualitas produk yang diterima sehingga konsumen merasa puas dengan produk $O^{\prime}$ Chicken yang disajikan karena rasanya yang gurih dan enak.

Pada indikator keterjangkauan harga dibandingkan dengan ayam goreng brand kompetitor yang berada tidak jauh dari lokasi usaha $O^{\prime}$ Chicken, dinilai cukup jauh berbeda sehingga mendapat nilai skor 4,02 dengan kategori berpengaruh. Dengan adanya paket harga yang ditawarkan, harga O'Chicken akan lebih terjangkau jika dibandingkan dengan membeli dalam jumlah satuan. 


\section{Lokasi/Tempat}

Indikator yang digunakan untuk melihat tanggapan konsumen terhadap lokasi outlet $O^{\prime}$ Chicken adalah lokasi strategis, mudah dijangkau sarana angkutan umum, halaman parkir yang memadai serta suasana atau kenyamanan outlet $O^{\prime}$ Chicken menjadi daya tarik tersendiri bagi konsumen yang ingin makan langsung ditempat atau konsumen yang ingin membeli produk O'Chicken untuk dikonsumsi dirumah. Tanggapan responden dan skor variabel harga pada bauran pemasaran disajikan pada Tabel 5.

Tabel 5. Tanggapan responden dan skor variabel harga pada bauran pemasaran (marketing mix) di O'Chicken Bukit Raya

\begin{tabular}{clcc}
\hline Variabel & \multicolumn{1}{c}{ Indikator } & Skor & Kategori \\
\hline Lokasi/tempat & Lokasi strategis dan menarik & 4,18 & Berpengaruh \\
& Akses transportasi mudah dijangkau & 4,06 & Berpengaruh \\
& Halaman parkir yang memadai & 3,16 & Cukup Berpengaruh \\
& Suasana/kenyamanan outlet memiliki daya tarik tersendiri & 3,82 & Berpengaruh \\
& Jarak tempuh O'Chicken dari rumah konsumen & 3,78 & Berpengaruh \\
\hline Rata-rata indikator & 3,81 & Berpengaruh \\
\hline
\end{tabular}

Tabel 5 menunjukkan bahwa lokasi usaha yang strategis dan menarik mendapat skor 4,18 dengan kategori berpengaruh. Lokasi usaha $O$ 'Chicken yang strategis umumnya sangat jelas jika dilihat dari tepi jalan raya dan juga berada dipusat keramaian seperti area sekolah, kampus, dan perumahan. Dengan adanya spanduk sebagai simbol usaha $O^{\prime}$ Chicken menjadikan lokasi usaha mudah ditemukan oleh konsumen yang ingin berbelanja.

Indikator halaman parkir yang memadai mendapat skor 3,16 dengan kategori cukup berpengaruh. Menunjukkan bahwa konsumen yang berkunjung ke $O$ 'Chicken dengan kendaraan roda dua atau roda empat parkirannya telah tersedia, tetapi konsumen beranggapan halaman parkir belum cukup memadai sehingga jika konsumen ramai, akan kesulitan dalam memarkirkan kendaraannya saat berbelanja di O'Chicken.

\section{Promosi}

Indikator yang digunakan pada variabel promosi adalah informasi tentang O'Chicken yang di promosikan menggunakan banner/spanduk, promosi dari mulut ke mulut, dan promosi menggunakan leaflet/media sosial sehingga terdapat 3 (tiga) item pertanyaan kuesioner. Tanggapan responden dan skor variabel promosi pada bauran pemasaran disajikan pada Tabel 6.

Tabel 6. Tanggapan responden dan skor variabel promosi pada bauran pemasaran (marketing mix) di O'Chicken Bukitraya

\begin{tabular}{clcc}
\hline Variabel & \multicolumn{1}{c}{ Indikator } & Skor & Kategori \\
\hline Promosi & Promosi menggunakan banner/spanduk & 3,66 & Berpengaruh \\
& Promosi dari mulut kemulut & 3,66 & Berpengaruh \\
& Promosi menggunakan leaflet/media sosial & 3,34 & Cukup Berpengaruh \\
\hline Rata-rata indikator & 3,55 & Berpengaruh \\
\hline
\end{tabular}


Tabel 6. pada indikator promosi menggunakan banner/spanduk mendapat skor 3,66 dengan kategori berpengaruh, ini menunjukkan bahwa responden mengetahui dan mengenal produk O'Chicken melalui banner/spanduk yang dilakukan oleh pihak O'Chicken sudah baik sehingga produk $O$ 'Chicken sudah dikenal oleh masyarakat.

Pada indikator promosi dari mulut kemulut mendapat skor 3,66 dengan kategori berpengaruh. Promosi dari mulut ke mulut dapat meningkatkan minat seseorang untuk membeli suatu produk. Banyak orang cenderung percaya dan tertarik untuk mencoba sesuatu yang direkomendasikan oleh orang-orang terdekat seperti sahabat, anggota keluarga, dan kerabat lainnya. Secara tidak langsung informasi dari mulut ke mulut sudah berpengaruh bagi konsumen sehingga produk O'Chicken sudah dikenal oleh masyarakat.

Indikator promosi menggunakan leaflet/media sosial mendapat skor 3,34 dengan kategori cukup berpengaruh, ini menunjukkan bahwa responden yang mengetahui dan mengenal produk O'Chicken melalui leaflet/brosur dan media sosial yang dilakukan oleh pihak O'Chicken belum cukup efisien dan belum menarik perhatian konsumen untuk melakukan pembelian produk O'Chicken.

\section{Pelayanan}

Pada variabel pelayanan, indikator yang digunakan adalah pelayanan yang ramah dan cepat tanggap dari karyawan $O^{\prime}$ Chicken dan layanan pesan antar (delivery order). Tanggapan responden dan skor variabel pelayanan pada bauran pemasaran (marketing mix) di O'Chicken Bukitraya dapat dilihat pada Tabel 7.

Tabel 7. Tanggapan responden dan skor variabel pelayanan pada bauran pemasaran (marketing mix) di O'Chicken Bukitraya

\begin{tabular}{cccc}
\hline Variabel & \multicolumn{1}{c}{ Indikator } & Skor & Kategori \\
\hline Pelayanan & Pelayanan yang ramah dan cepat tanggap & 4,34 & Sangat Berpengaruh \\
& Layanan pesan antar (delivery) & 4,24 & Sangat Berpengaruh \\
\hline & Rata-rata indikator & 4,29 & Sangat Berpengaruh \\
\hline
\end{tabular}

Tabel 7 pada indikator pelayanan yang ramah dan cepat tanggap mendapat skor 4,34 dengan kategori sangat berpengaruh, ini menunjukkan bahwa konsumen sangat puas dengan pelayanan yang diberikan oleh pihak O'Chicken dikarenakan konsumen memperoleh penjelasan yang baik mengenai produk serta paket hemat yang ditawarkan oleh pihak O'Chicken. Pelayanan yang baik akan berdampak terhadap promosi usaha, jika konsumen merasa puas terhadap pelayanan yang diterima, akan mendorong konsumen untuk melakukan promosi dari mulut kemulut sehingga permintaan produk O'Chicken semakin meningkat.

Indikator layanan pesan (delivery) mendapat skor 4,24 dengan kategori sangat berpengaruh. Hal ini menunjukkan bahwa layanan pesan antar ini sangat membantu konsumen terutama bagi wanita Pekanbaru 
karir yang tidak sempat untuk mengantarkan bekal makan siang untuk putra/putrinya. Di sisi lain, adanya layanan pesan antar (delivery) dapat membantu konsumen untuk mengalokasikan waktunya lebih efektif dan efisien, hal ini dikarenakan waktu yang seharusnya digunakan untuk membeli makan siang dapat dialokasikan untuk kegiatan lainnya.

Keputusan akhir konsumen dalam membeli produk O'Chicken dengan mempertimbangkan variabel bauran pemasaran yaitu produk, harga, tempat, promosi dan pelayanan. Konsumen sebelum melakukan pembelian akan melihat bagaimana produknya, harga yang ditawarkan, lokasi usaha yang strategis, promosi usaha, serta pelayanan yang diberikan kepada konsumen menjadi salah satu pertimbangan akhir dalam membeli produk $O^{\prime}$ Chicken, sebagaimana dijelaskan pada Tabel 8.

Tabel 8. Variabel Bauran Pemasaran O'Chicken

\begin{tabular}{|c|c|c|}
\hline Variabel & Nilai Skor & Kategori \\
\hline Produk & 4,23 & Sangat Berpengaruh \\
\hline Harga & 4,09 & Berpengaruh \\
\hline Lokasi & 3,81 & Berpengaruh \\
\hline Promosi & 3,58 & Berpengaruh \\
\hline Pelayanan & 4,29 & Sangat Berpengaruh \\
\hline Rata-rata & 4,00 & Berpengaruh \\
\hline
\end{tabular}

Berdasarkan Tabel 8 pada variabel produk dengan nilai skor 4,23 karena O'Chicken menawarkan produk ayam goreng maupun produk ayam olahan lainnya dengan kualitas, rasa, tekstur, kerenyahan, warna, kebersihan produk, paket produk yang berkualitas organik sehingga disukai oleh konsumen karena lebih sehat dengan kualitas ayam yang organik.

Variabel kedua adalah harga dengan nilai skor 4,09 karena $O$ 'Chicken menawarkan ayam goreng dengan kualitas organik dengan harga yang terjangkau dan tersedianya paket harga ayam goreng maupun berbagai macam jenis produk olahan lainnya yang berbahan dasar ayam organik dengan harga yang murah sehingga diminati diberbagai kalangan.

Pada variabel ketiga yaitu lokasi dengan nilai skor 3,81 karena konsumen yang datang berbelanja dominan bermukim tidak jauh dari lokasi usaha $O^{\prime}$ Chicken dan jarak tempuh dari rumah konsumen O'Chicken cukup dekat sehingga konsumen lebih memilih berbelanja di O'Chicken karena lebih menghemat waktu dan tenaga.

Variabel keempat adalah variabel promosi dengan nilai skor 3,58, dengan adanya berbagai promosi yang dilakukan pihak O'Chicken dengan menggunakan banner/spanduk, promosi dari mulut kemulut, dan promosi menggunakan leaflet/media sosial sehingga konsumen tertarik untuk datang membeli ayam $O^{\prime}$ Chicken.

Variabel kelima adalah variabel pelayanan dengan nilai skor 4,29 karena keramahan pelayan O'Chicken merupakan sikap yang ditampilkan oleh pelayan kepada konsumen selama proses pembelian dan kecepatan penyajian yang diperlukan untuk menyajikan makanan dan minuman

147 Analisis Bauran Pemasaran Franchise O’chicken Di Kecamatan Bukitraya Kota Pekanbaru 
kepada konsumen, serta adanya layanan pesan antar yang menarik minat konsumen terutama wanita karir

\section{KESIMPULAN DAN SARAN}

\section{Kesimpulan}

Berdasarkan hasil penelitian dapat disimpulkan bahwa analisis bauran pemasaran dalam melakukan pembelian $O^{\prime}$ Chicken dipengaruhi oleh lima variabel bauran pemasaran seperti produk, harga, lokasi, promosi dan pelayanan mendapat skor rata-rata 4,00 dengan kategori berpengaruh. Variabel produk dengan rata-rata skor 4,23 berkategori sangat berpengaruh, indikator produk yang mendapat skor tertinggi adalah kebersihan produk dengan skor 4,60 kategori sangat berpengaruh. Variabel harga dengan rata-rata skor 4,09 berkategori berpengaruh, indikator harga yang mendapat skor tertinggi adalah harga sesuai dengan kualitas produk dengan skor 4,24 kategori sangat berpengaruh. Variabel tempat dengan rata-rata skor 3,81 berkategori cukup berpengaruh, indikator tempat yang mendapat skor tertinggi adalah lokasi strategis dan menarik dengan skor 4,18 kategori berpengaruh. Variabel promosi dengan rata-rata skor 3,58 dengan kategori berpengaruh, indikator promosi yang mendapat skor tertinggi adalah promosi menggunakan banner atau spanduk dan promosi dari mulut-kemulut dengan skor 3,66 kategori berpengaruh. Variabel pelayanan dengan skor rata-rata 4,29 dengan kategori sangat berpengaruh, indikator yang mendapat skor tertinggi adalah pelayanan yang ramah dan cepat tanggap dengan skor 4,34 kategori sangat berpengaruh.

\section{Saran}

Diharapkan pemilik usaha $O^{\prime}$ Chicken agar memperhatikan dan meningkatkan promosi usaha agar usaha lebih dikenal oleh masyarakat dan pemilik usaha $O^{\prime} C h i c k e n$ agar memperhatikan fasilitas parkir, dan perluasan parkir agar konsumen lebih mudah memarkirkan kendaraannya dan menambah kenyamanan konsumen dalam melakukan pembelian di tempat usaha O'Chicken.

\section{DAFTAR PUSTAKA}

Assauri, Sofjan. 2011. Manajemen Pemasaran. Penerbit : PT. Raja Grafindo Persada. Jakarta.

Ridwan. 2002. Skala Pengukuran Variabel-Variabel Penelitian. Alfabeta. Bandung.

Hurriyati, Ratih. 2010. Bauran Pemasaran dan Loyalitas Konsumen. CV. ALFABETA. Bandung. Jones C.P. 2000. Investment : Analysis and Management ( $7^{\text {th }}$ ed). New York : JohnWiley \& Sons Kotler, Philip. 2008. Manajemen Pemasaran. Edisi ke dua belas. Jilid kedua. Jakarta : PT. Indeks. Shimp, Terence, A. 2000. Periklanan Promosi. Jakarta: Penerbit Erlangga. Pekanbaru 
Sugiono, 2015. Metode Penelitian dan Pengembangan (Research and Development). CV. Alfabeta. Bandung

Zeithaml dan Bitner. 2003. Service Marketing Integrating Customer Focus Across the Firm, $\mathbf{3}^{\text {rd }}$. Boston. McGrowHill/Irwin. 